\title{
RESEARCH PAPER \\ ESTIMATION OF SURFACE ENERGY FLUXES FROM BARE GROUND IN A TROPICAL STATION USING PRIESTLEY TAYLOR METHOD
}

\author{
M. O Adeniyi and E. F. Nymphas \\ Department of Physics, \\ University of Ibadan, Nigeria
}

\begin{abstract}
This investigation was designed to test the performance of Priestley Taylor method in the partitioning of the available energy into sensible and latent heat fluxes in a tropical site. Compared to eddy covariance measured fluxes, the conventional Priestley Taylor constant $\left(\alpha_{P T}\right)$ of 1.25 gave low coefficient of determination and high bias error for both sensible and latent heat fluxes. It overestimated latent heat flux in the noon and afternoon but underestimated sensible heat flux. The bias error reduced and the coefficient of determination increased for sensible heat flux when $\alpha_{P T}$ value was reduced to 1.0. The bias error for latent heat also reduced but the coefficient of determination did not change with the reduction in $\alpha_{P T}$ value. The root mean square error reduced with the reduction in the $\alpha_{P T}$ value. Compared to measured fluxes, coefficient of determination of sensible heat flux ranged from 0.82 to 0.90 while that of latent heat flux ranged from 0.78 to 0.9. Priestley Taylor method is recommended for partitioning of available energy into its component sensible and latent heat fluxes.
\end{abstract}

Keywords: $\alpha_{P T}$ value, energy, latent heat ,flux

\section{INTRODUCTION}

The monitoring of atmospheric turbulent fluxes (sensible and latent heat) at the land surface is crucial to the determination and modeling of the land -atmosphere energy and mass exchange processes that are applicable in weather, climate, agricultural and hydrological studies, Priestley and Taylor (1972). The fluxes can be measured or estimated. The Eddy covariance (EC) method is a standard technique that is widely used to monitor turbulent fluxes of sensible and latent heat.
Unfortunately the equipment is not available in many stations in West Africa due to the expenses and expertise involved. Profile measurements are done in most stations since they are less expensive. From the profile measurement of temperature, wind speed, relative humidity and vapour pressure, various estimation methods can be used to find the fluxes of sensible and latent heats. The Bowen ratio energy balance (BREB) method is a widely used estimation method that enforces closure on the energy balance equation ( Jegede et al., 2001; Balogun 


\section{2}

et al., 2002; Jegede et al., 2004; Kim et al., 1989; Heilman et al., 1989; Gutierre and Meinzer, 1994; Fritschen and Simpson 1989).

The Priestley Taylor parameterization has not been widely applied in West Africa, though it has been proved reliable in various parts of the globe (Sumner and Jacobs, 2005; Gardelin and Lindstrom, 1996; Agam et al., 2010). There is the need to validate all the available estimation methods using standard measurement system.

The Nigerian Micrometeorological Experiment (Nimex) group started measurement in 2004 during which eddy covariance measurement of turbulent fluxes and profile measurement of meteorological parameters were done.

This investigation is based on the assessment of the performance of Priestley Taylor model in partitioning of surface energy flux into sensible and latent heat portions.

\section{STUDY AREA}

The Nimex-1 experimental field was located on a farm land at Obafemi Awolowo University, Ile-Ife $\left(7^{0} 33^{\prime} \mathrm{N}, 4^{0} 33^{\prime} \mathrm{E}\right)$ Nigeria. The site is a level terrain of about $100000 \mathrm{~m}^{2}$ with an elevation of $288 \mathrm{~m}$ above sea level. Generally in Nigeria there are two seasons: wet (April to October) and dry (November to March). These seasons are influenced by two air masses namely south-westerlies coming from the Atlantic Ocean and north-easterlies from the Sahara desert respectively. The position of the Inter -tropical convergence zone (ITCZ) across West Africa affects the seasons (Figure 1). The ITCZ is at its minimum position in January and it reaches its maximum position in August. There is rainfall at the region below the ITCZ and dryness at the region above it (Adedokun, 1978 and Balogun, 1981). The investigation was conducted during the transition period from dry to wet season, precisely from 19 February to 9 March, 2004.

\section{METHODS}

\section{Measurement}

Slow Response Measurements

During the course of the experiment, profile measurements of the following parameters were done: wind speed at eight levels; wind direction at $14.8 \mathrm{~m}$; wet and dry bulb temperatures at three levels; soil surface temperature; soil temperature at three depths; and soil heat flux at three depths. Complete description of the equipment used in this investigation is given in Table 1. Jegede et al., (2004) and Mauder et al., (2007) reported the preliminary results of this experiment.

Day of year (DOY)s 61, 63, 66 and 67 were selected for this investigation based on their completion or closeness to completion of the profile and EC data. The experimental field was almost bare soil, since it was cleared just before the commencement of the experiment and soil heat flux at $2 \mathrm{~cm}$ depth was used, so leaf area index and energy storage in the soil can be neglected in the treatment of data.

\section{Fast Response Measurements}

The eddy covariance system used on Nimex-1 field comprised of a three dimensional Metek USA-1 sonic anemometer used to measure high frequency wind velocity components $(\mathrm{u}, \mathrm{v}$ and w) and air temperature (T) and a Campbell Scientific krypton hygrometer (KH2O) used to measure high frequency signals of water vapour density. The sensors were installed on a $2.5 \mathrm{~m}$ mast. The sonic anemometer was sampled at 16 $\mathrm{Hz}$ while the krypton hygrometer was sampled at $8 \mathrm{~Hz}$.

Visual test was carried out on daily basis to check the quality of the data from the slow response equipment (Foken, 2003). A software package written by Mauder and Foken (2004) was used to check the quality and to analyze the fast response data. The software package was employed to carry out the following processes:

- Removal of physically impossible values following the spike detection method of Vickers and Mahrt(1997) based on Hojstrup (1993). 


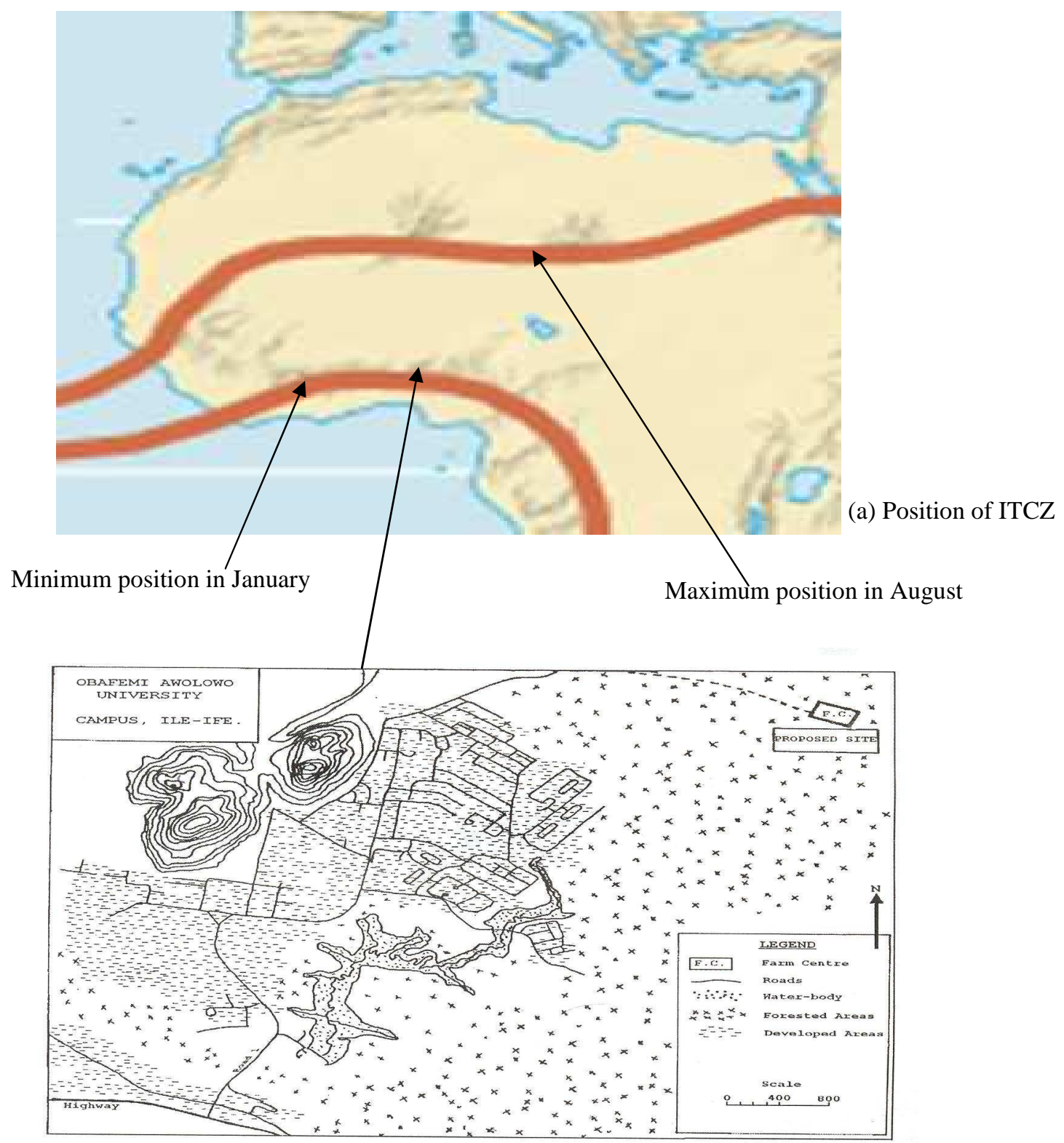

(b) Nimex-1 station

Fig 1: (a) Position of ITCZ over West Africa in January and August (b) Nimex- 1 Station

- The difference in the sampling frequency of sonic anemometer and krypton hygrometer necessitated the application of cross correlation analysis for each averag- ing interval of both sensors for the determination of the time delay between them. This was done. 
Table 1: List of Equipment deployed during Nimex-1

\begin{tabular}{|c|c|c|c|}
\hline Parameter & Sensor & Accuracy & Levels of measurement (m) \\
\hline Data acquisition & $\begin{array}{l}\text { Campbell Scientific Data-logger } \\
\text { CR10X }\end{array}$ & Not applicable & Not applicable \\
\hline Wind speed & $\begin{array}{l}\text { Vector Instruments } \\
\text { Cup anemometer A101ML/ } \\
\text { A100L2 }\end{array}$ & $1 \%$ & $\begin{array}{l}0.7,1.2,2.2,3.3,5.2,7.2 \\
10.2 \text { and } 14.8\end{array}$ \\
\hline Wind direction & $\begin{array}{l}\text { Vector Instruments Wind vane } \\
\text { W200P }\end{array}$ & $\pm 2^{0}$ & 14.8 \\
\hline $\begin{array}{l}\text { Wet and dry bulb air } \\
\text { temperature }\end{array}$ & $\begin{array}{l}\text { Theodor Friedrichs Frakenberger } \\
\text { Psychrometer }\end{array}$ & $\pm .05{ }^{0} \mathrm{C}$ & $0.9,4.9$ and 10.0 \\
\hline $\begin{array}{l}\text { Soil surface tempera- } \\
\text { ture }\end{array}$ & $\begin{array}{l}\text { Heitronics Infrared Pyrometer } \\
\text { KT1582D }\end{array}$ & $\pm 0.5^{\circ} \mathrm{C}$ & 1.8 \\
\hline Soil temperature & $\begin{array}{l}\text { Campbell Scientific Thermistor } \\
\text { Thermocouple }\end{array}$ & $\pm 1^{0} \mathrm{C}$ & $0.05,0.10$ and 0.30 (depth) \\
\hline Soil heat flux & $\begin{array}{l}\text { Hukseflux HFP01SC self cali- } \\
\text { brating } \\
\text { Heat flux plate }\end{array}$ & $\pm 3 \%$ & $\begin{array}{l}0.02,0.05,0.10 \text { and } 0.30 \\
\text { (depth) }\end{array}$ \\
\hline Net radiation & $\begin{array}{l}\text { Kipp and Zonen CNR1 net radi- } \\
\text { ometer }\end{array}$ & $\pm 10 \%$ (daily total) & 1.9 \\
\hline 3D wind speed & $\begin{array}{l}\text { Metek USA-1 3-D ultrasonic } \\
\text { anemometer }\end{array}$ & $0.01 \mathrm{~ms}^{-1}$ & 2.48 \\
\hline Water vapour content & $\begin{array}{l}\text { Campbell Scientific KH20 kryp- } \\
\text { ton } \\
\text { Hygrometer }\end{array}$ & $0.15 \mathrm{~m}^{3} \mathrm{~g}^{-1} \mathrm{~cm}^{-1}$ (sensitivity) & 2.43 \\
\hline $\begin{array}{l}\text { Volumetric soil } \\
\text { moisture }(\%)\end{array}$ & $\begin{array}{l}\text { Campbell Scientific CS616 water } \\
\text { content reflectometer }\end{array}$ & $\pm 3 \%$ of water content & 0.05 (depth) \\
\hline
\end{tabular}

- Sonic temperature was corrected using Liu et al. (2001) method.

- Planar fit method of Wikzak et al. (2001) was applied for coordinate transformation.

- Following Moore (1986), the spectral mod- els of Kaimal et al. (1972) and Hojstrup (1981) were used for spectral correction.

- Schotanus et al. (1983) method was applied in the conversion of buoyancy flux into sensible heat flux. 
- Webb et al. (1980) method was applied in the corrections for fluctuations for density fluctuation in calculating the water vapour.

- The methods of Foken and Wichura (1996) and Foken et al. (2004) were applied to test for steady state conditions and well- developed turbulence.

\section{Theory and Calculation}

\section{Priestly Taylor Parameterization}

The Priestley-Taylor parameterization of the sensible heat flux, $Q_{H}$ and the latent heat flux, $Q_{E}$ are respectively given by DeBruin (1983):

$Q_{H}=\frac{\left[\left(1-\alpha_{P T}\right) S_{c c}+\gamma\right]\left(Q_{N}-Q_{G}\right)}{S_{c c}+\gamma}$

$Q_{E}=\frac{\alpha_{P T} S_{c c}\left(Q_{N}-Q_{G}\right)}{S_{c c}+\gamma}$

where $\mathrm{S}_{c c}$ is the change of specific humidity with temperature, at saturation it is given by :

$\frac{d q_{s a t}}{d T}=\frac{\varepsilon L_{v} \bar{q}_{s a t}}{R \bar{T}^{2}} \equiv S_{c c}(\bar{T})$

$Q_{N}=$ net radiation

$Q_{G}=$ ground heat flux

$\gamma=0.667 \mathrm{KhPa}^{-1}$ is the psychometric constant for $\mathrm{p}=1000 \mathrm{hPa}$ and $\mathrm{T}=20^{\circ} \mathrm{C}$.

The Priestley Taylor constant, $\alpha_{P T}$ is used to make the equation applicable to unsaturated conditions.

$Q_{N}-Q_{G}$ in equation (2) is the available energy that controls the exchange processes at the surface.

$\mathrm{q}=$ specific humidity (If the air is saturated, $q$

$\left.=q_{s a t}\right)$.

The latent heat of evaporation $\mathrm{Lv}$ was com- puted from $\mathrm{L}_{\mathrm{v}}(\mathrm{J} / \mathrm{kg})=\left[12.501-0.00237 . \mathrm{T}\left({ }^{0} \mathrm{C}\right)\right]$ $10^{6}$

The universal gas constant, $\mathrm{R}=287.04 \mathrm{~J} / \mathrm{kg}$ $\mathrm{K}), \mathrm{T}=$ temperature

The value of $\alpha_{\mathrm{PT}}$ is generally 1.25 or 1.26 for well watered surfaces.

$\varepsilon=0.622\left(\mathrm{~g}_{\text {water }} / \mathrm{g}_{\text {air }}\right)$ is the ratio of gas constants for air and water vapour. The value of $\mathrm{q}_{\mathrm{sat}}$ can be obtained as a function of temperature $(\mathrm{T})$ by using a variation of Tenten's formula (Bolton 1980) as:

$q_{\text {sat }}=0.622 \frac{e_{\text {sat }}}{P}$

where

$e_{s a t}=(0.6112 \mathrm{kPa}) \cdot \exp \left[\frac{17.67 \cdot(T-273.16)}{T-29.66}\right]$

Determination of $\alpha_{\mathrm{PT}}$ value for unsaturated surface

The period of Nimex-1 was the transition between dry and wet seasons which is always characterized by unsaturated soil surface due to little or no precipitation. The $\alpha_{\mathrm{PT}}$ values during Nimex- 1 were computed according to Eichinger et al. (1996).

$\alpha_{P T}=\frac{1+[\gamma C /(\Delta+\gamma)]}{1-[\gamma C /(\Delta+\gamma)]^{2}}$

where

$\Delta=\left.\frac{d e_{s a t}}{d T}\right|_{T} \approx \frac{e_{s a t}\left(T_{g}\right)-e_{s a} a}{T_{g}-T_{a}}$

$C=\frac{\left(e_{s a t} a-e_{a}\right)}{\left(e_{\text {sat }}\left(T_{g}\right)-e_{a}\right)} \quad$ and

$C=\frac{\left(1-R H_{a}\right) e_{s a} a-\left(1-R H_{g}\right) e_{s a t}(T g)}{\left(R H_{g} e_{s a t}\left(T_{g}\right)-e_{a}\right)}$ for unsaturated 
Surfaces.

$T_{g}=$ surface temperature, $T_{a}=$ air temperature, $e$ $\left(T_{g}\right)=$ water vapour pressure at the surface temperature, $e_{a}=$ water vapour pressure in the air, $e_{s a t}\left(T_{g}\right)$ and $e_{s a t} a$ are the saturation vapour pressure at temperature $T_{g}$ and $T_{a}$ respectively. $R H_{a}$ and $R H_{g}$ are the relative humidity of the air and the surface respectively.

\section{RESULTS AND DISCUSSION \\ Result for DOY 66}

Sensible and latent heat fluxes estimated using Priestley Taylor parameterization versus measured values for DOY 66 are shown in Fig. 2a.The effect of the varying Priestley Taylor constant on the estimated fluxes was examined by plotting the bias between the measured and the estimated sensible and latent heat fluxes (Fig.3) Table 2 shows the statistics coefficient of determination $\left(\mathrm{R}^{2}\right)$ and root mean square error (RMSE) between estimated and measured fluxes for the period of investigation.

Figs 2 and 3 clearly show the overestimation of sensible heat flux in the morning and evenings and its underestimation at about noon to afternoon. There was also a general underestimation of latent heat flux in the morning and evenings but it was overestimated in the afternoon.

Sensible and latent heat fluxes biases were high in the afternoon but low in the morning and evening probably because that was the time of maximum fluxes and the deviation at that time can be high as well. The biases reduced with the reduction in the $\alpha_{\mathrm{PT}}$ value.

Sensible heat flux had lower bias and higher $\mathrm{R}^{2}$ than latent heat flux.(Figs. 3a, 4, 5 and Table 2 ). The bias value of sensible heat flux reduced from maximum value of 66.9 to less than 40 $\mathrm{Wm}^{-2}$ with most points between -10 and +20 $\mathrm{W} \mathrm{m}{ }^{-2}$ while the bias value of latent heat flux varied mostly between -2.2 and $-60 \mathrm{~W} \mathrm{~m}^{-2}$ with a few (2)points higher than $-60 \mathrm{~W} \mathrm{~m}^{-2}$ in the improved estimation. In general there was a better representation of $\mathrm{Q}_{\mathrm{E}}$ flux with reduced $\alpha_{\mathrm{PT}}$, though there was no change in $\mathrm{R}^{2}$ value throughout.

The $\alpha_{P T}$ value for DOY 66 was computed to be 1.0 using Eichinger et al. (1996) formulation for $\alpha_{P T}$. With Priestley Taylor constant of 1.25 the coefficient of determination $\left(\mathrm{R}^{2}\right)$ for senble heat flux was low (0.74) but with the reduction to 1.0 , the $\mathrm{R}^{2}$ value increased to 0.83 (Fig 4). Fig. 2a also show a better representation of sensible heat flux with reduced Priestley Taylor constant. Comparing Fig. 2a-d, it can be noticed that the reduction in the $\alpha_{\mathrm{PT}}$ value adjusted the fluxes such that the sensible heat flux was increased in the afternoon while the latent heat flux was reduced. Considering the RMSE, $\alpha_{\mathrm{PT}}$ $=1$ (calculated value) gave the least RMSE values for both fluxes.

\section{Result of DOY 67}

The diurnal variations of the estimated and measured sensible and latent heat fluxes for varying $\alpha_{\mathrm{PT}}$ of 1.25 and 1.0 for DOY 67 are shown in Fig. 2b. Figure 3b presents the biases between the estimated and measured sensible and latent heat fluxes for DOY 67. The estimated fluxes were approaching measured fluxes with the reduction of Prietley Taylor constant. The $\alpha_{P T}$ value for DOY 67 was computed to be 1.0 using Eichinger et al., (1996) formulation for $\alpha_{P T}$.

The $Q_{E}$ bias value reduced from between -70.9 and 110.4 to between -70.9 and $46.7 \mathrm{~W} \mathrm{~m}^{-2}$. The $Q_{H}$ bias moved from between -105.2 and 35.2 to between -41.9 and $35.2 \mathrm{~W} \mathrm{~m}^{-2}$.

\section{Result for DOY 61 and 63}

Measured fluxes on DOY 61 and 63 did not extend to 24 hours, however the available points were used. The reduction in the $\alpha_{\mathrm{PT}}$ value brought the estimated fluxes closer to the measured ones for DOYs 61 and 63 like the other DOYs (Figures 2c and d; Figures $3 \mathrm{c}$ and d). The $R^{2}$ value increased while the RMSE value reduced with $\alpha_{P T}$ value of 1.0 for sensible heat flux. The $\mathrm{R}^{2}$ value remained constant for latent heat flux but the RMSE value reduced (Table 2, Figs 4 and 5). 
Estimation of surface energy fluxes... 47

Table 2: Statistics between the estimated and observed surface fluxes using varying $\alpha_{\mathrm{PT}}$

\begin{tabular}{cccccccccc}
\hline \multicolumn{3}{c}{ DOY 61 } & \multicolumn{3}{c}{ DOY 63 } & \multicolumn{3}{c}{ DOY66 } & \multicolumn{3}{c}{ DOY 67 } \\
& $\mathrm{Q}_{\mathrm{H}}$ & $\mathrm{Q}_{\mathrm{E}}$ & $\mathrm{Q}_{\mathrm{H}}$ & $\mathrm{Q}_{\mathrm{E}}$ & $\mathrm{Q}_{\mathrm{H}}$ & $\mathrm{Q}_{\mathrm{E}}$ & $\mathrm{Q}_{\mathrm{H}}$ & $\mathrm{Q}_{\mathrm{E}}$ \\
\hline \multicolumn{3}{c}{ Coefficient of determination } \\
\hline
\end{tabular}
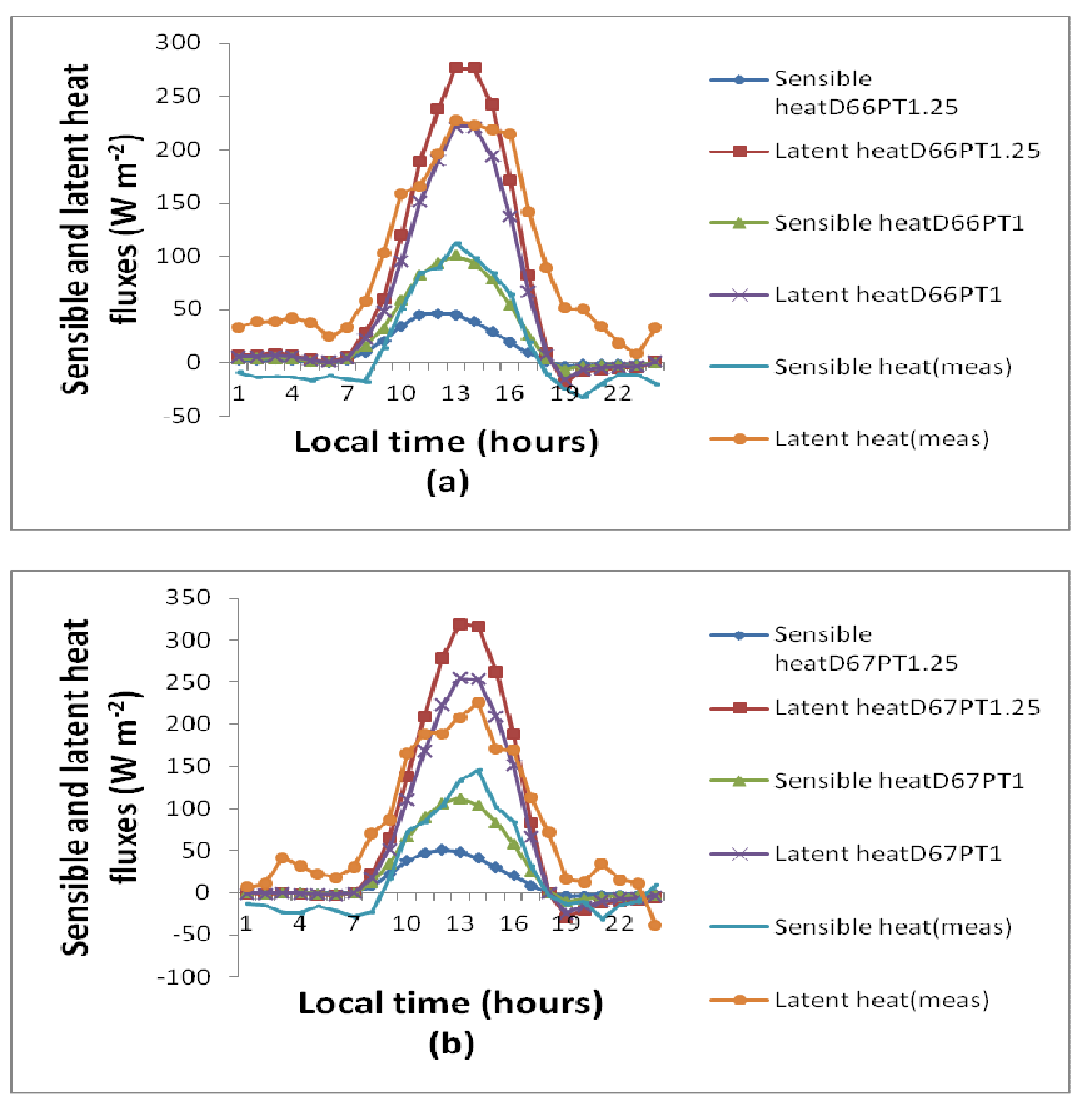

Fig 2a, b : Sensible and latent heat fluxes with Priestley Taylor constant of 1 and 1.25 for DOYs(a) 66, (b) 67 

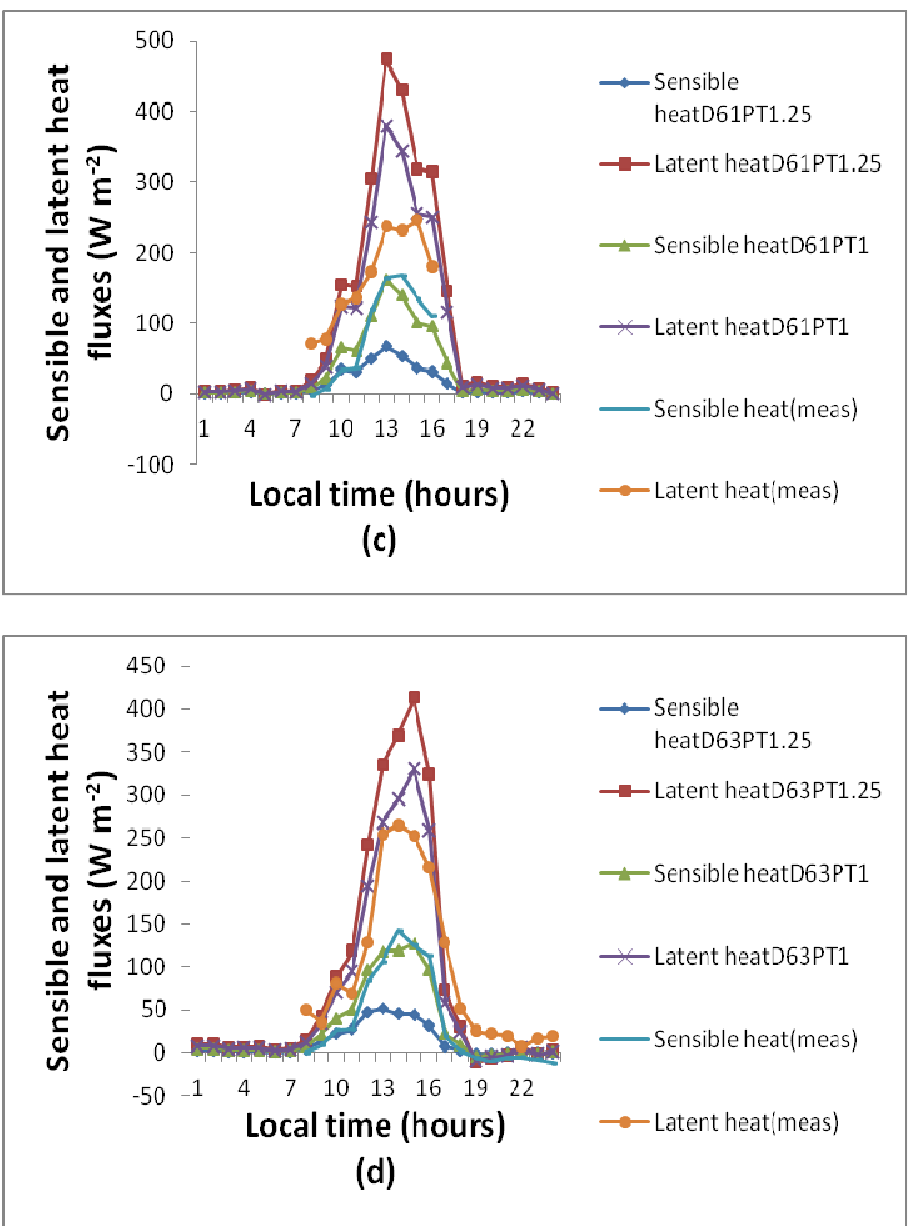

Fig 2c, d: Same as Fig 2a, b except for DOYs (c) 61 and (d) 63

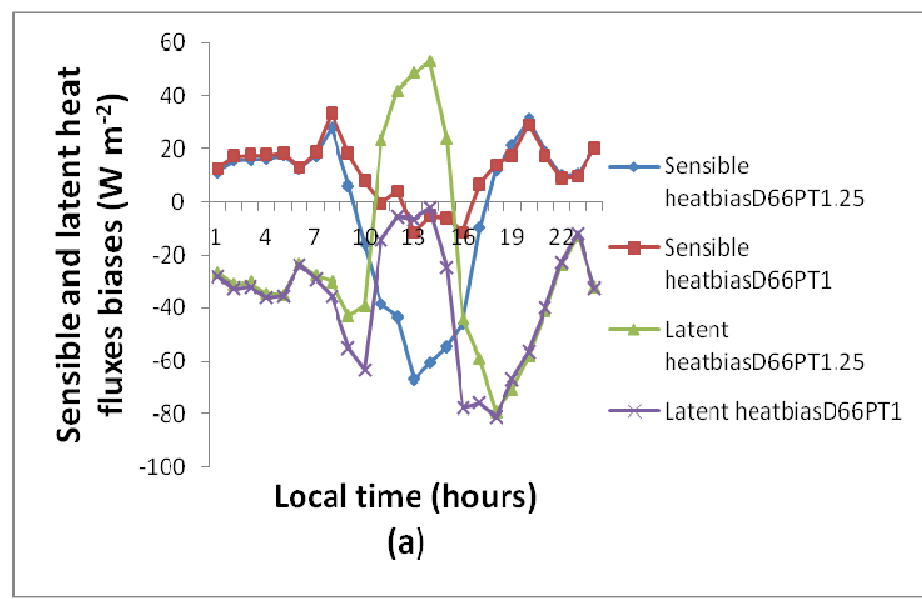

Journal of Science and Technology @ KNUST April 2013 
Estimation of surface energy fluxes... 49

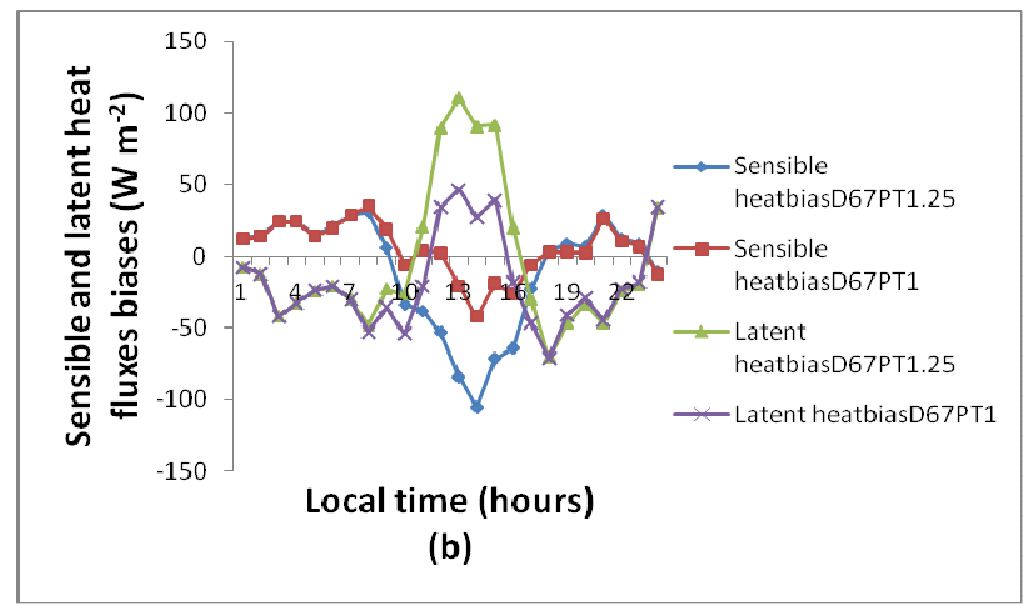

Fig 3a, b: Biases for sensible and latent heat fluxes for DOYs (a) 66, (b) 67
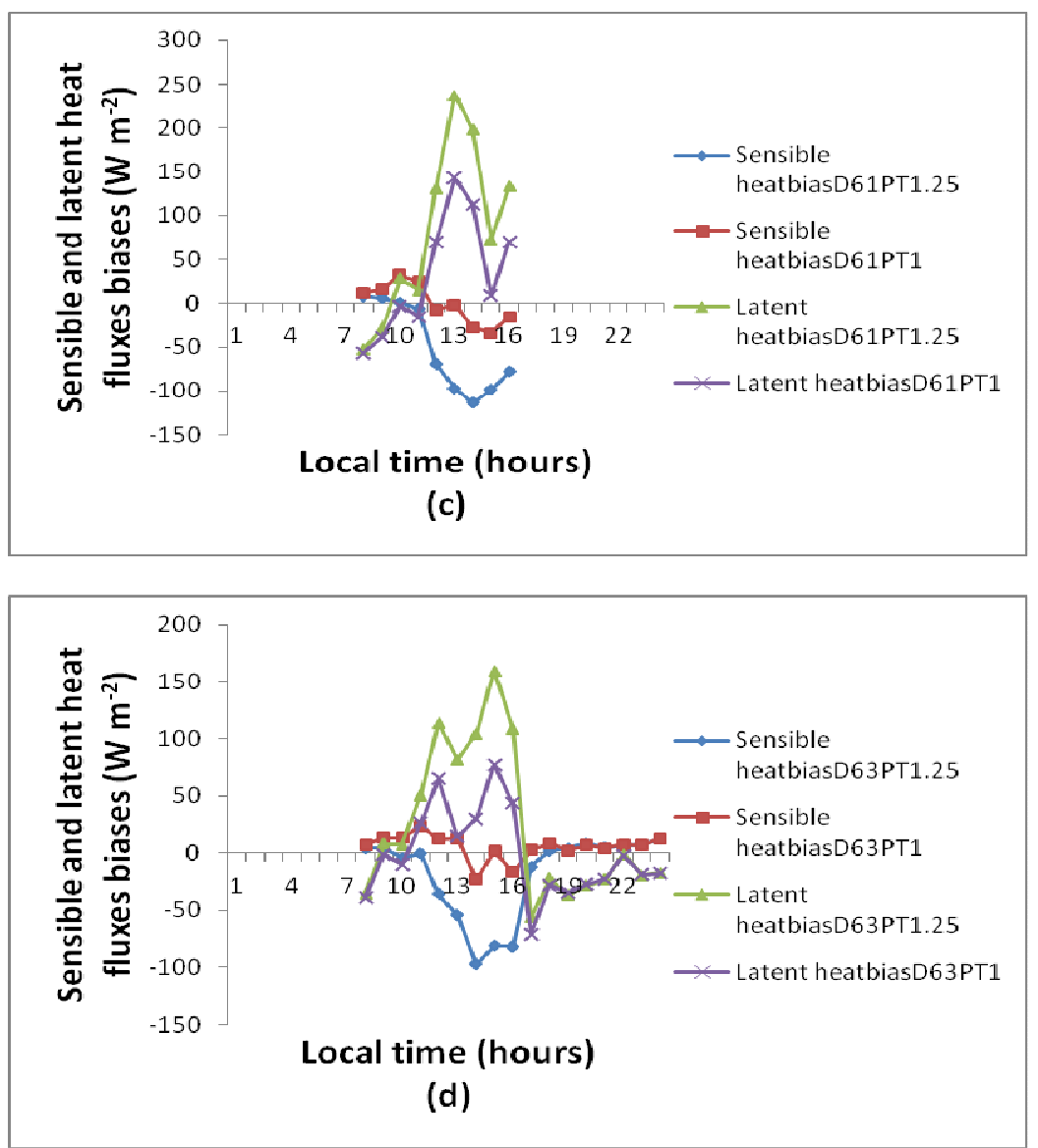

Fig: 3c,d: Same as Fig 3a, b except for (c) DOY 61 and (d) DOY 63

Journal of Science and Technology @ KNUST April 2013 


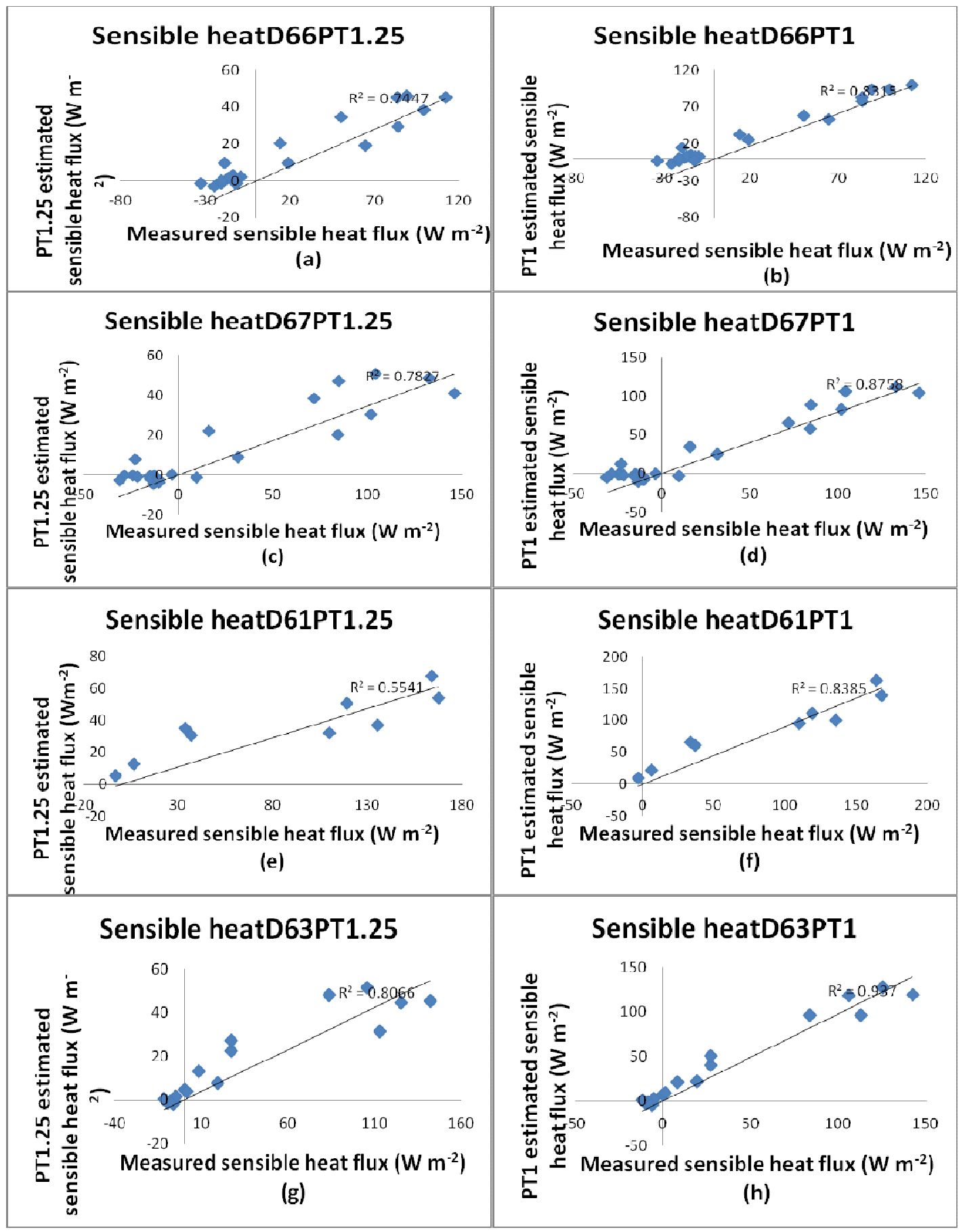

Fig 4: Scatter plots of measured and estimate sensible heat flux 
Estimation of surface energy fluxes... 51

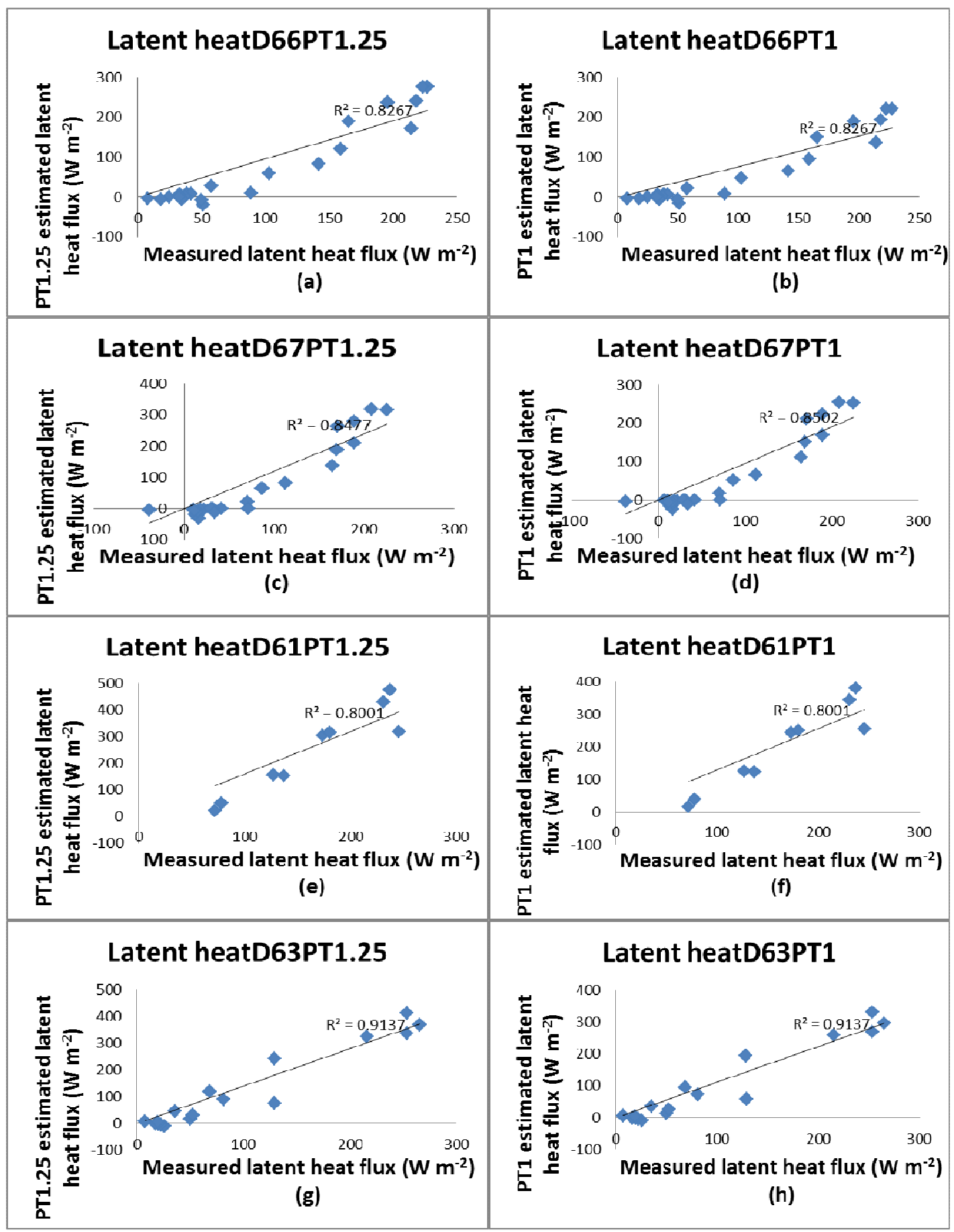

Fig 5: Scatter plots of measured and estimated latent heat flux 


\section{Overall Performance of Priestley Taylor} Parameterization

The soil moisture was very low during the period of the experiment since the rainy season was just starting and there were gaps in the rain days. In particular there was no rain in all the days considered in this investigation. Generally soil moisture was decreasing (negative trend) through the DOYs considered. Daily average soil moisture of $14,11,9$ and $8 \%$ were recorded for DOYs 61, 63, 66 and 67 respectively.

The average daily bias error in sensible heat flux (excluding DOY 61due to its few hourly values) was between 3.5 and $23.1 \mathrm{~W} \mathrm{~m}^{-2}$ with $\alpha_{\mathrm{PT}}$ of 1 , this is very small. The average daily bias error for latent heat flux was between 0.9 and $37.0 \mathrm{Wm}^{-2}$, which is also between acceptable limit. The RMSE values reduced with reduction in the $\alpha_{\mathrm{PT}}$ value.

The adjustment in the $\alpha_{\mathrm{PT}}$ value did not affect the $R^{2}$ value of latent heat but increased that of sensible heat. High $\mathrm{R}^{2}$ values of 0.83 to 0.94 were obtained for sensible heat flux and 0.80 to 0.91 for latent heat flux (Table 2 and Figs 4 and 5) with $\alpha_{\mathrm{PT}}$ value of 1.0. The $R^{2}$ values obtained were comparable with those obtained by $\mathrm{Su}$ (2002) who estimated sensible and latent heat fluxes using surface energy balance system, he obtained $\mathrm{R}^{2}$ values ranging from 0.81 0.88 and $0.43-0.87$ for sensible and latent heat flux respectively. Summer and Jacobs (2005) got $\mathrm{R}^{2}$ value of 0.81 for evapotranspiration using Penmman Monteith parameterization. Gardelin and Lindstrom (1996) got $\mathrm{R}^{2}$ value ranging between 0.79 and 0.94 using Priestley Taylor method. Albertson et al. (1995) used flux variance method to estimate sensible heat flux that has $\mathrm{R}^{2}$ value of 0.88 .

In this investigation, the fluctuation in sensible heat flux with varying $\alpha_{\mathrm{PT}}$ was such that sensible heat flux and its $\mathrm{R}^{2}$ value increased as $\alpha_{\mathrm{PT}}$ reduced. Latent heat flux reduced with reduction in $\alpha_{\text {PT }}$ value while its $R^{2}$ value remained constant. This is contrary to the report by
Pereira and Nova (1992) that $\alpha_{\mathrm{PT}}$ value is linearly related to sensible heat in a positive way. This is probably due to the site of the experiments.

\section{CONCLUSION}

Priestley Taylor parameterization was used to partition the available energy from a bare surface in a tropical station into its sensible and latent heat parts. The parameterization was verified by eddy covariance measurements during the transition period from dry to wet season of 2004. In general the diurnal values of the estimated sensible and latent heat fluxes compared well with measurements. When the Priestley Taylor constant of 1.25 was used, the estimated sensible and latent heat fluxes had higher bias error values but the use of Eichinger et al., (1996) formulated $\alpha_{P T}$ values gave reliable estimates of the sensible and latent heat fluxes. Acceptable coefficient of determinations and root mean square errors were obtained for both fluxes when compared with previous estimation works. This method can be successfully applied in this area.

\section{ACKNOWLEDGEMENT}

This research was supported by International Programmes in the Physical Sciences (IPPS) Sweden, African Regional Centre for Space Sciences and Technology Education, Ile- Ife, Nigeria and National Space Research and Development Agency, Abuja, Nigeria. The work was prepared at the Abdus Salam International Centre for Theoretical Physics, Trieste Italy.

The Authors are grateful to other members of Nimex group for making this research a reality.

\section{REFERENCES}

Adedokun, J. A. (1978). West African precipitation and dominant atmospheric mechanisms. Archive fur Meteorologie Geophysik und Bioklimatologie Series A 27: 287-310.

Agam, N., Kustas, W. P. , Anderson, M.C., Norman, J. M., Colaizzi, P. D., Howell, T. A., prueger, J. H., Meyer, T. P. and Wilson, 
T. B., (2010). Application of the Priestly Taylor approach in a two- source surface energy balance model. Journal of Hydrometeorology. 11: 185-198.

Albertson, J. D., Parlange, M. B., Katul, G. G., Chu, C., Stricker, H. and Tyler, S., (1995). Sensible heat flux from arid regions: A simple flux-variance method. Water Resources Research. 31(4): 969-973.

Balogun, E. E. (1981). Seasonal and Spatial variations in thunderstorm activity over Nigeria. Weather 36: 192-197

Balogun, A. A., Jegede, O. O., Foken, T. and Olaleye, J. O. (2002). Estimation of sensible and latent heat fluxes over bare soil using Bowen ratio energy balance method at a humid tropical site. Journal of the African Meteorological Society 5(1): 63-71

Bolton, D. (1980). The computation of equivalent potential temperature. Monthly Weather Review 108: 1046-1053

De Bruin, H.A.R. (1983). A model for the Priestley-Taylor parameter. Journal of Climatology and Applied Meteorology 22: 572578

Eichinger, W. E., Parlange, M. B. and Stricker, H. (1996). On the concept of equilibrium evaporation and the value of the PriestlyTaylor coefficient. Water Resources Research 32: 161-164.

Foken, T. (2003). Angewandte Meteorologie. Mikrometeorologische Methoden. Springer, Heidelberg, Germany.

Foken, T., Go“ckede, M., Mauder, M., Mahrt, L., Amiro, B. D. and Munger, J. W. (2004). Post-field data quality control. In: Lee X, Massman WJ, Law BE (editors) Handbook of micrometeorology. A guide for surface flux measurements. Kluwer, Dordrecht, Netherlands
Estimation of surface energy fluxes... 53

Foken, T. and Wichura, B. (1996). Tools for quality assessment of surface-based flux measurements. Agricultural and Forest Meteorology 78: 83-105

Fritschen, L. J. and Simpson, J. R. (1989). Surface energy and radiation balance systems: general description and improvements. Journal of Applied Meteorology 28(7): 680-689

Gardelin, M. and Lindstrom, G. (1996). Priestly - Taylor evapotranspiration in HBV simulations. Nordic Hydrology 28(415): 233-246

Gutierrez, M. V. and Meinzer, F. C. (1994). Energy balance and latent heat flux partitioning in coffee hedgerows at different stages of canopy development. Agricultural and Forest Meteorology 68(3-4): 173-186

Heilman, J. L., Brittin, C. L. and Neale, C. M. U. (1989). Fetch requirements for Bowen ratio measurements of latent and sensible heat fluxes. Agricultural and Forest Meteorology 44(3-4): 261-273

Højstrup, J. (1981). A simple model for the adjustment of velocity spectra in unstable conditions downstream of an abrupt change in roughness and heat flux. Bound-Layer Meteorology, 21: 341- 356

Højstrup, J. (1993). A statistical data screening procedure. Measurement Science and Technology 4(2): 153-157

Jegede, O.O., Foken, T. Balogun, A. A. and Abimbola, O. J. (2001). Bowen ratio determination of sensible and latent heat fluxes in a humid tropical environment at Ile- Ife, Nigeria. Mausam 52(4): 669-678

Jegede, O. O., Mauder, M., Okogbue, E. C., Foken,T., Balogun, E. E., Adedokun, J. A., Oladiran, E. O. , Omotosho, J. A., Balogun, A. A., Oladosu, O. R., Sunmonu, L. A., Ayoola, M. A., Aregbesola, T. O., Ogolo, E. O., Nymphas, E. F., Adeniyi, M. O., Olatona, 


\section{$54 \quad$ Adeniyi and Nymphas}

G. I. Ladipo, K. O., Ohamobi, S. I., Gbobaniyi E. O. and Akinlade G. O. (2004). The Nigerian Micrometeorological Experiment (NIMEX-1): An overview. Ife Journal of Science 6(2): 191-202

Kaimal J. C.,Wyngaard J. C., Izumi Y. and Cote O.R. (1972). Spectral characteristics of surface layer turbulence. Quarterly Journal of the Royal Meteorological Society 98: 563589

Kim, J., Verma, S. B. and Rosenberg, N. J. (1989). Energy balance and water use of cereal crops. Agricultural and Forest Meteorology 48(1-2): 135-147

Liu H., Peters G. and Foken T. (2001). New equations for sonic temperature variance and buoyancy heat flux with an omnidirectional sonic anemometer. Bound-Layer Meteorology 100: 459-468

Mauder M. and Foken T. (2004). Documentation and instruction manual of the eddy covariance software package TK2. Arbeitsergebnisse, Universitat Bayreuth, Abt. Mikrometeorologie, 26: 1-44

Mauder, M., Jegede, O. O., Okogbue, E. C., Wimmer, F. and Foken T. (2007). Surface energy balance measurements at a tropical site in West Africa during the transition from dry to wet season. Theoretical and Applied Climatology 89: 171-183

Moore C. J. (1986). Frequency response corrections for eddy correlation systems. BoundLayer Meteorology 37: 17-35
Priestly, C. H. B. and Taylor, R. J. (1972). On the assessment of surface heat flux and evaporation using large-scale parameters. Monthly Weather Review 100: 81-92

Schotanus P, Nieuwstadt F. T. M. and DeBruin H. A. R. (1983). Temperature measurement with a sonic anemometer and its application to heat and moisture fluctuations. BoundLayer Meteorology 26: 81-93

Su, Z. (2002). The surface energy balance system (SEBS) for estimation of turbulent heat fluxes. Hydrology and Earth System Sciences $6(1): 85-99$

Sumner, D. M. and Jacobs, J. M. (2005). Utility of Penman-Monteith, Priestly-Taylor, reference evaporation and pan evaporation methods to estimate pasture evapotranspiration. Journal of Hydrology 308, 81-104

Vickers, D. and Mahrt, L. (1997). Quality control and flux sampling problems for tower and aircraft data. Journal of Atmospheric and Oceanic Technology 14: 512-526

Webb E. K., Pearman, G. I. and Leuning, R. (1980). Correction of the flux measurements for density effects due to heat and water vapour transfer. Quarterly Journal of the Royal Meteorological Society 106: 85-100

Wilczak, J. M., Oncley, S. P. and Stage, S. A. (2001). Sonic anemometer tilt correction algorithms. Bound-Layer Meteorology 99: $127-150$ 